\title{
PENGARUH KUALITAS PRODUK DAN KUALITAS PELAYANAN TERHADAP KEPUASAN PELANGGAN TOYOTA AVANZA DI SINGARAJA
}

\author{
I W. Widiantara ${ }^{1}$, Trianasari $^{2}$ \\ 12Jurusan Manajemen, Universitas Pendidikan Ganesha, Singaraja \\ e-mail widiantara301@gmail.com ${ }^{1}$, nanatrianasari01@gmail.com²
}

\begin{abstract}
Abstrak
Penelitian ini bertujuan untuk menguji pengaruh (1) kualitas produk terhadap kepuasan pelanggan, (2) kualitas pelayanan terhadap kepuasan pelanggan, dan (3) kualitas produk dan kualitas pelayanan terhadap kepuasan pelanggan Toyota Avanza. Desain penelitian menggunakan kuantitatif kausal. Subjek penelitian ini adalah pengguna mobil Toyota Avanza tipe $1.3 \mathrm{G} \mathrm{M} / \mathrm{T}$ di Singaraja yang mengetahui seluk beluk Daihatsu Xenia tipe $1.3 \mathrm{R} \mathrm{M} / \mathrm{T}$ serta berusia lebih dari dua puluh tahun dan telah menggunakanya selama lebih dari satu tahun, yang berjumlah 100 responden. Data dikumpulkan dengan menggunakan instrumen berupa kuesioner yang terdiri dari 14 pernyataan yang kemudian diubah menjadi data interval dan dianalisis menggunakan metode regresi linier berganda. Dari analisis yang telah dilakukan didapatkan hasil bahwa (1) kualitas produk berpengaruh positif dan signifikan terhadap kepuasan pelanggan, (2) kualitas pelayanan berpengaruh positif dan signifikan terhadap kepuasan pelanggan, dan (3) kualitas produk dan kualitas pelayanan berpengaruh signifikan terhadap kepuasan pelanggan Toyota Avanza.
\end{abstract}

Kata kunci: kepuasan, kualitas pelayanan, kualitas produk.

\begin{abstract}
This study aims to test the influence of (1) product quality on customer satisfaction, (2) quality of service to customer satisfaction, and (3) product quality and service quality to customer satisfaction of Toyota Avanza. Design research using caesal quantitative. The subject of this study was a user of Toyota Avanza type $1.3 \mathrm{G} \mathrm{M} / \mathrm{T}$ in Singaraja who knew the ins and outs of Daihatsu Xenia type $1.3 R$ $M / T$ and was more than twenty years old and had been using it for more than a year, which amounted to 100 respondents. The data was collected using a questionnaire instrument consisting of 14 statements which were later converted into interval data and analyzed using multiple linear regression methods. From the analysis that has been done obtained results that (1) product quality has a positive and significant effect on customer satisfaction, (2) service quality has a positive and significant effect on customer satisfaction, and (3) product quality and service quality have a significant effect on Toyota Avanza customer satisfaction.
\end{abstract}

Keywords: product quality, quality of service, satisfaction

\section{Pendahuluan}

Dalam era globalisasi saat ini, mobilitas manusia dituntut untuk cepat dalam melakukan perpindahan maupun melakukan kegiatan lainnya. Untuk memenuhi hal tersebut manusia membutuhkan alat transportasi untuk berpindah dari tempat asal ke tempat tujuan dengan waktu sesingkat mungkin walau jarak yang ditempuh realtif jauh. Transportasi yang paling banyak digunakan oleh manusia adalah tranportasi darat, seperti contoh sepeda motor dan mobil. Mobil merupakan salah satu tranportasi yang efektif dalam memberikan kenyamanan bagi pengguna dan penumpangnya. Mobil dapat melindungi penggunanya dari panas dan hujan selain itu mobil juga dapat mengurangi resiko berbahaya saat berkendara, karena mobil dapat melindungi pengguna dari hantaman yang fatal. Dengan demikian pengguna dapat memobilisasi dirinya dengan cepat namun juga aman. Selain itu pengguna mobil juga memiliki status sosial yang lebih baik daripada pengguna motor, karena anggapan bahwa mobil hanya dimiliki oleh orang-orang yang memiliki kondisi keuangan menengah keatas. Salah satu merek mobil yang terkenal di Indonesia ialah Toyota. Toyota memiliki peran besar dalam membangun transportasi di Indonesia. Salah satu jenis mobil yang mudah untuk ditemukan adalah MPV 
(Multi Purpose Vehicle), yang merupakan mobil yang didesain khusus untuk menampung banyak penumpang. Salah satu jenis mobil MPV yang dimiliki Toyota adalah Avanza.

Avanza merupakan mobil MPV yang paling sering ditemui di Indonesia. Sangat mudah untuk menemukan mobil Avanza, hal ini sejalan dengan data penjualan mobil MPV yang dihimpun oleh Top Brand Index. Menurut data yang mereka himpun Toyota Avanza memimpin penjualan mobil MPV di Indonesia, diikuti oleh merek lain. Selain itu jenis lain MPV dari Toyota yaitu Kijang Inova juga masuk kedalam empat besar penjualan mobil MPV di Indonesia. Berikut ini merupakan data pangsa pasar mobil MPV di Indonesia yang dihimpun oleh www.topbrand-award.com dari tahun 2017 sampai tahun 2019, data sebagai berikut: Dari data di atas dapat dilihat bahwa Toyota dengan Toyota Avanza terus memimpin penjualan mobil MPV di Indonesia. Namun bila lebih diperhatikan data pangsa pasar tersebut, pangsa pasar dari Toyota Avanza terus mengalami penurunan dari 44,1\% di tahun 2017 , kemudian menjadi 39,3\% pada tahun 2018 dan akhirnya menjadi 30,6\% di tahun 2019 ke tahun. Tentu ini merupakan kondisi yang berbahaya bagi Toyota Avanza karena produk-produk mobil MPV dari pesaing mengalami hal yang sebaliknya, yaitu terus mengalami pertumbuhan seperti contoh Daihatshu Xenia dan Grand Max yang mengalami pertumbuhan yang cukup signifikan.

Bila sudah mengalami hal seperti ini, manajemen Toyota dituntut untuk segera menanggulangi masalah ini, karena apabila tidak ditangani akan berdamapak berbahya bagi perusahaan. Salah satu cara untuk menanggulangi masalah ini adalah memahami masalah apa yang sedang dihadapi sehingga berdampak negatif ke penjualan mobil Toyota Avanza. Salah satu yang mungkin menjadi penyebab ialah kurangnya rasa puas akan produk dari Toyata ini. Rasa ketidakpuasan ini mucul karena berbagai faktor. Menurut Irawan (2008:37) dimensi pembangun yang dapat memengaruhi kepuasan pelanggan ialah persepsi pelanggan terhadap kualitas dari suatu produk, nilai produk tersebut, kualitas dari pelayanan yang diberikan oleh penawar produk serta faktor pribadi yang bersifat keadaan sementara. Apabila pelanggan tidak merasa puas maka mereka tidak akan memilih Avanza lagi dan tidak akan memberikan rekomendasi kepada orang lain untuk memilih mobil Toyota Avanza, namun mereka akan melakukan rekomendasi untuk memilih produk pesaing yang memiliki kualitas pelayanan lebih bagus serta memiliki kualitas produk yang sama atau bahkan lebih baik.

Kualitas produk dan kualitas pelayanan merupakan hal yang sangat penting bagi perusahaan apabila mereka ingin mendapat kepuasan dari pelanggan. Menurut Kotler (2007) kualitas pelayanan merupakan upaya perushaan dalam meningkatkan kualitas secara terus menerus terhadap proses, produk dan pelayanan yang dihasilkan perusahaan. Sedangkan Tjiptono (2007) mengungkapkan kualitas pelayanan ialah suatu proses pemenuhan akan kebutuhan maupun keinginan pelanggan dan juga kebenaran dari informasi yang disampaikan sehingga dapat memenuhi harapan pelanggan. Artinya dengan memberikan pelayanan terbaik kepada calon maupun yang telah menggunakan mobil Toyota Avanza tentu hal ini akan menimbulkan rasa bahwa mereka dihormati dan dibutuhkan oleh Toyota namun bila yang terjadi adalah hal yang sebaliknya tentu pengguna merasa kecewa dan merasa tidak dihormati, hal ini sejalan dengan penelitian yang dilakukan oleh Haryanto (2013) yang menyatakan pengaruh kualitas layanan dan kualitas layanan berpengaruh secara signifikan terhadap kepuasan pelanggan Gojek Online.

Tidak jauh berbeda dengan kualitas pelayanan, kualitas produk juga menjadi tolak ukur pelanggan puas atau tidak terhadap produk yang mereka beli. Menurut Kotler dan Amstrong (2008) kualitas produk menyangkut setiap aspek dalam fungsi-fungsi dari produk tersebut baik itu dari aspek durabilitas, aspek reliabilitas, aspek ketepatan, aspek kemudahan pengoperasian dan aspek reparasi produk termasuk juga atribut produk lainnya. Sedangkan menurut Nasution (2004) kualitas produk ialah suatu faktor kesamaan antara produk dan pengguna atau pelanggan baik dari segi daya tahan yang dapat bertahan lama dan tidak mudah rusak, dari nilai estetika dimana dapat meningkatkan status sosial pelanggan, adanya korelasi yang positif antara daya tahan dan nilai estetika yang diberikan. Sebagai contoh, pelanggan yang tidak puas dengan kualitas produk yang mereka beli karena produk tersebut mengalami permasalahan atau tidak sesuai dengan persepsi mereka, terlebih nilai estetika yang ditimbulkan harusnya dapat meningkatkan status sosial pelanggan tersebut namun 
ternyata produk cepat rusak sehingga memunculkan persepsi bahwa produk yang dibeli murahan atau imitasi. Penelitian yang dilakukan oleh Yuninda (2019) dimana mendapat hasil kualitas produk berpengaruh positif terhadap kepuasan pelanggan. Oleh sebab itu semakin tinggi tingkat kualitas produk menyebabkan semakin tingginya kepuasan pelanggan dan juga mendukung kualitas pelayanan yang lebih tinggi serta biaya yang lebih rendah. Karena pelanggan merasa kualitas produk mereka tidak dapat terpenuhi oleh perusahaan maka mereka akan memberikan komentar negatif kepada perusahaan dan memberikan rekomendasi untuk tidak membeli Toyota Avanza. Hal ini disebabkan kualitas pelayanan yang kurang baik dan juga karena kualitas yang tidak sepadan dengan harga jual produk bila dibandingkan dengan produk dari merek lain. Hal ini sejalan dengan penelitian yang dilakukan Amanah (2010) dimana kualitas produk dan kualitas pelayanan mempengaruhi kepuasan pelanggan secara simultan.

Menurunya penjualan mobil Toyota Avanza disinyalir karena kepuasan pelanggan yang menurun yang disebabkan kualitas produk dan kualitas pelayanan yang kurang baik bila dibandingkan dengan pelayanan dan produk dari pesaing, hal ini sesuai dengan teori Irawan (2008:37) yang menyatakan salah satu faktor yang mempengaruhi kepuasan pelanggan adalah persepsi pelanggan mengenai kualitas produk dan kepuasan pelanggan selain dipengaruhi oleh kualitas produk juga ditentukan oleh nilai, kualitas pelayanan dan faktorfaktor lain yang bersifat pribadi serta yang bersifat situasi sesaat. Untuk mengetahui kebenaran tersebut, peneliti melakukan pra survei. Jumlah dari jawaban kuesioner awal tersebut diakumulasi dan dikategorikan berdasarkan kriteria skor total pada masing-masing variabel. Kegiatan ini dilakukan dengan menyebarkan kuesioner awal yang diisi oleh 10 orang pengguna mobil Toyota Avanza tipe $1.3 \mathrm{G} \mathrm{M} / \mathrm{T}$. Tipe $1.3 \mathrm{G} \mathrm{M} / \mathrm{T}$ dipilih karena tipe ini merupakan tipe paling laris seperti yang diutarakan oleh Rouli Sijabat selaku Public Relation Manager PT Toyota-Astra Motor yang dikutip dari www.gridoto.com. Selain menggunakan Toyota Avanza tipe 1.3 G M/T, para responden juga harus mengetahui seluk beluk mengnenai mobil pembanding. Mobil pembading yang digunakan merupakan mobil yang memang dirancang untuk bersaing dengan Toyota Avanza tipe $1.3 \mathrm{G} \mathrm{M} / \mathrm{T}$, mobil tersebut ialah Daihatsu Xenia tipe $1.3 \mathrm{R} \mathrm{M} / \mathrm{T}$.

Tempat dilakukanya pengambilan sampel yaitu Kota Singaraja, sebagai kota pendidikan dan bukan pusat ekonomi tentu ekonomi masyarakat kota ini menengah bila dibandingkan dengan kota Denpasar, Badung, dan Gianyar. Dengan kondisi ekonomi menengah tersebut tentu akan sulit bagi mayoritas orang untuk membeli kendaraan yang lebih mahal seperti jenisjenis city car atau SUV yang terdiri dari Toyota Rush, Pajero Sport, atau Honda Jazz. Kondisi ekonomi tentu akan mendorong banyak orang untuk memilih mobil dengan harga yang relatif terjangkau bila dibandingkan dengan jenis mobil lain namun tetap memiliki fungsi dan penampilan yang baik, tentu MPV merupakan solusi dari permasalahan trsebut. Alasan ini yang mendasari mengapa Kota Singaraja dipilih sebagai lokasi untuk digunakan dalam penelitian ini. Toyota Avanza tipe $1.3 \mathrm{G} \mathrm{M} / \mathrm{T}$ memiliki fitur, kinerja, dan ketahanan yang kurang dibandingkan mobil Daihatsu Xenia sehingga nilai dari variabel kualitas produk dalam kategori yang rendah.Data menunjukan kualitas pelayanan memiliki nilai yang rendah, bagi responden pelayanan yang diberikan oleh Toyota masih tidak dapat memenuhi keinginan akan jasa yang diharapkan oleh pengguna Toyota Avanza tipe $1.3 \mathrm{G} \mathrm{M} / \mathrm{T}$.

Kepuasan pelanggan pengguna Toyota Avanza tipe $1.3 \mathrm{G} \mathrm{M} / \mathrm{T}$ tergolong rendah. Hal ini dapat disebabkan oleh kurang-puasnya pelanggan dengan produk Toyota Avanza tipe $1.3 \mathrm{G}$ $\mathrm{M} / \mathrm{T}$. Beberapa pelanggan menyampaikan bahwa produk tidak sesuai dengan persepsi mereka, serta terdapat beberapa komplain yang dilakukan oleh pengguna terkait kualitas produk. Hal ini diduga menyebabkan reandahnya kepuasan pelanggan terhadap mobil Toyota Avanza tipe $1.3 \mathrm{G} \mathrm{M} / \mathrm{T}$. Apabila tidak ditindaklanjuti, pengguna Toyota Avanza dapat beralih dan memilih produk atau merek lain pada pembelian selanjutnya.Dari observasi awal tersebut dipandang perlu mengkaji dugaan rendahnya kepuasan pelanggan Toyota Avanza Singaraja melalui sebuah penelitian. Selain itu peneliti juga ingin membuktikan apakah penelitian ini sejalan dengan beberapa penelitian sebelumnya. Menurut Aryanti dan Suyanto (2019) kualitas pelayanan, kualitas produk dan citra merek secara bersama-sama berpengaruh signifikan 
terhadap kepuasan pelanggan. Selain itu penelitian lain yang dilakukan oleh Saidini dan Arifin (2012) mendapatkan hasil bahwa kualitas produk dan kualitas pelayanan berpengaruh signifikan terhadap kepuasan konsumen. Dari hasil-hasil penelitian tersebut maka peneliti memiliki referensi dan pedoman dalam penelitian ini, sehingga diharapkan dengan refrensi tersebut dapat menghidarkan dari terjadinya salah konsepsi dalam penelitian ini.

Peneliti ingin membuktikan bahwa memang telah terjadi penurunan kepuasan pelanggan Toyota Avanza di Singaraja. Kualitas produk dan kualitas pelayanan terindikasi menjadi penyebab penurunan kepuasan pelanggan, sehingga kedua variabel ini memiliki alasan yang kuat untuk dijadikan faktor menurunnya kepuasan pelanggan dan berdampak pada penjualan. Pemaparan dan uraian-uraian di atas dapat dijadikan dasar dalam pandangan bahwa perlu dilakukan penelitian mengenai pengaruh kualitas produk dan kualitas layanan terhadap kepuasan pelanggan. Berdasarkan latar belakang yang telah dipaparkan di atas, masalah-masalah yang dapat penulis identifikasi adalah sebagai berikut. (1) Penjualan Toyota Avanza terus mengalami penurunan yang sangat signifikan dalam beberapa tahun belakangan. (2) Penjualan produk pesaing mengalami hal sebaliknya, dimana penjualan produk mobil MPV mereka mengalami kenaikan yang cukup signifikan. (3) Penurunan disebabkan ketidakpuasan pelanggan akan kualitas pelayanan yang ditawarkan dan kualitas produk yang mereka dapat. Dalam penelitian yang akan dilakukan, agar tidak melebar permasalahannya maka penulis membatasi masalah yaitu seputar variabel kualitas produk, kualitas pelayanan dan juga kepuasan pelanggan saja, penelitian ini tidak akan membahas variabel diluar tiga variabel yang telah disebutkan tersebut. Objek yang akan diteliti adalah mobil merek Toyota yang berjenis Toyota Avanza, sehingga subjek yang digunakan adalah pengguna Toyota Avanza saja dan tidak akan membahas lebih dalam mengenai merek dan jenis mobil lain.

Menurut Kotler (2005:49) kualitas produk ialah seluruh ciri khas yang dimiliki produk untuk memenuhi seluruh keinginan dan kebutuhan yang telah dijanjikan. Tjiptono (2006) kualitas produk ialah baik itu barang atau jasa memiliki pengaruh yang signifikan terhadap kepuasan konsumen, loyalitas konsumen, pangsa pasar, pembelian kembali, profitabilitas pasar retensi konsumen, dan informasi mulut ke mulut atau word of mouth. Teori hubungan tersebut juga didukung hasil penelitian yang dilakukan oleh Yuninda (2019) dimana mendapat hasil kualitas produk berpengaruh positif terhadap kepuasan. Oleh sebab itu semakin tinggi tingkat kualitas produk menyebabkan semakin tingginya kepuasan pelanggan dan juga mendukung kualitas pelayanan yang lebih tinggi serta biaya yang lebih rendah.

$\mathrm{H} 1$ : Ada pengaruh pengaruh kualitas produk terhadap kepuasan pelanggan pada pengguna mobil Toyota Avanza di Singaraja.

Menurut Lupiyoadi (2001) kualitas pelayanan dan kepuasan pelanggan keritkatan yang solid. Dimana ketika konsumen merasa puas dengan pelayanan yang didapat maka berarti pelayanan tersebut berkualitas dan memunculkan perasaan puas. Hal tersebut didukung oleh teori Kotler (2002), menjelaskan bahwa kualitas pelayanan dan kepuasan produk serta profitabilitas perusahaan memiliki hubungan yang sangat erat. Teori-teori tersebut juga didukung oleh hasil penelitian Haryanto (2013) yang menyatakan Pengaruh kualitas layanan terhadap kepuasan pelanggan, dengan hasil uji hipotesis kualitas layanan berpengaruh secara signifikan terhadap kepuasan pelanggan Gojek Online.

H2: Ada pengaruh pengaruh kualitas pelayanan terhadap kepuasan pelanggan pada pengguna mobil Toyota Avanza di Singaraja.

Saat ini persaingan bisnis sangat ketat, sehingga banyak pilihan produk yang tersebar diseluruh dunia yang menyebabkan konsumen memiliki banyak pilihan baik itu pilihan utama maupun hanya alternatif, dengan kondisi tersebut maka konsumen akan dapt memilter produkproduk sejenis untuk dicari produk yang memiliki nilai kualitas produk dan kualitas pelayanan yang tertinggi (Kotler, 2005). Oleh sebab itu kualitas produk dan kualitas pelayanan secara bersama-sama dapat mempengaruhi tinggi rendahnya kepuasan pelanggan. Teori ini didukung oleh teori Menurut Irawan (2008:37) dimensi pembangun yang dapat memengaruhi kepuasan pelanggan ialah persepsi pelanggan terhadap kualitas dari suatu produk, nilai produk tersebut, kualitas dari pelayanan yang diberikan oleh penawar produk serta faktor 
pribadi yang bersifat keadaan sementara. Teori hubungan tersebut juga didukung hasil penelitian yang menyatakan ada pengaruh kualitas produk dan kualitas pelayanan terhadap kepuasan pelanggan secara simultan sesuai dengan hasil penelitian yang dilakukan Amanah (2010) dimana kualitas produk dan kualitas pelayanan mempengaruhi kepuasan pelanggan secara simultan. Oleh sebab itu semakin tinggi tingkat kualitas produk menyebabkan semakin tingginya kepuasan pelanggan dan juga mendukung kualitas pelayanan yang lebih tinggi serta biaya yang lebih rendah.

H3: Ada pengaruh pengaruh kualitas produk dan kualitas pelayanan terhadap kepuasan pelanggan pada pengguna mobil Toyota Avanza di Singaraja.

\section{Metode}

Subjek pada penelitian ini merupakan pengguna kendaraan beroda empat Toyota Avanza pada Singaraja, sedangkan objek pada penelitian ini merupakan Toyata Avanza. Sampel merupakan bagian menurut jumlah dan ciri yang pada miliki sang populasi tadi Sugiyono (2014:116). Pengambilan sampel pada penelitian ini memakai metode purposive sampling. Metode purposive sampling, yaitu pengembangan sampel yang dipilih secara cermat menggunakan menggambil objek penelitian yang selektif dan memiliki karakteristikkarakteristik yang spesifik. Sugiyono (2014:122) menyatakan bahwa purposive sampling adalah teknik penentuan sampel menggunakan petimbangan tertentu. Pertimbangan yang dimaksud yaitu keriteria yang telah pada tentukan peneliti untuk memilih sampel pengambilan data. Kriteria pada penelitian ini yaitu pengguna kendaraan beroda empat Toyota Avanza tipe 1.tiga $\mathrm{G} \mathrm{M} / \mathrm{T}$ yang mengetahui seluk beluk Daihatsu Xenia tipe 1.tiga $R \mathrm{M} / \mathrm{T}$ dan berusia lebih menurut 2 puluh tahun dan sudah menggunakanya selama lebih menurut satu tahun. Lokasi yang dipilih yaitu Kota Singaraja, lantaran syarat ekonomi kota ini cocok menggunakan pangsa pasar menurut Toyota Avanza. Ferdinand (2006), menyatakan banyaknya jumlah sampel pada penelitian tergantung menurut jumlah parameter yang destimasi. Pedomannya merupakan 5-10 kali jumlah parameter yang pada estimasi. Penelitian ini memakai 14 indikator sebagai akibatnya banyaknya responden yang pada ambil menjadi sampel merupakan $14 \times 5$ $=70$ sampel minimal dan $14 \times 10=140$ sampel maksimal. Agar penelitian bisa berjalan efisien pada penggunaan asal daya tetapi permanen efektif pada pengambilan warta maka jumlah sampel yang dipakai pada penelitian ini berada diantara batas atas dan batas bawah sebagai akibatnya jumlah responden yang dipakai yaitu sebesar 100 responden.

Pada penelitian ini mekanisme pengumpulan data yang dipakai merupakan menggunakan memakai berita umum. Kuesioner atau daftar pernyataan adalah teknik pengumpulan data yang dilakukan menggunakan cara menyusun pernyataan-pernyataan yang sifatnya tertutup dan terbuka menggunakan jawaban yang sudah disediakan dan wajib diisi sang responden menggunakan cara menentukan galat satu cara lain jawaban yang tersedia bersama alasanya. Kuesioner menjadi instrumen pengukuran data ordinal yag adalah pembagian terstruktur mengenai menurut indikator variabel sebelumnya dipakai untuk pengumpulan data dilapangan, terlebih dulu diuji taraf validitas dan reliabilitasnya. Jawaban responden terhadap pertanyaan ini dikatakan reliabel apabila masing-masing pertanyaan dijawab secara konsisten atau jawaban nir boleh rambang sang lantaran masing-masing pertanyaan hendak mengukur hal yang sama.

Suatu berita umum dikatakan valid apabila pertanyaan dalam berita umum bisa untuk menyampaikan sesuatu yang akan diukur sang berita umum tadi. Dalam penelitian ini metode dan teknik analisi data yang dipakai yaitu analisis regresi linier berganda menggunakan memakai aplikasi SPSS versi 23.0 untuk Windows. Regresi berganda dipakai untuk menganalisis kuatnya interaksi menurut variabel kualitas produk $(\mathrm{x} 1)$ dan variabel kualitas 
pelayanan (x2) terhadap variabel kepuasan pelanggan (y) sebelum data diolah ke analisis regresi berganda, terlebih dahulu pada uji menggunakan pengujian perkiraan klasik, lantaran kondisi untuk analisis regresi berganda merupakan bebas menurut perkiraan-perkiraan klasik. Jenis data pada penelitian ini merupakan kuantitatif. Data kuantitatif penelitian ini merupakan skor jawaban responden pengguna kendaraan beroda empat Toyota Avanza pada Singaraja. Dalam penelitian ini asal data yang dipakai merupakan data primer. Data Primer diperoleh menurut jawaban responden melalui penyebaran kuisioner pada konsumen yang sebagai responden terpilih. Metode pengumpulan data yang dipakai pada penelitian ini merupakan menjadi berikut, data berupa warta melalui pengisian berita umum tentang lingkungan kerja non fisik, kompetensi intelektual, dan pandangan hidup kerja yang diperoleh menurut jawaban responden.

\section{Hasil Dan Pembahasan}

Model analisis linier berganda dipakai untuk mengetahui imbas kualitas produk dan kualitas pelayanan terhadap kepuasan pelanggan Toyota Avanza secara simultan juga parsial. Pengujian dilakukan menggunakan mengunakan aplikasi SPSS 23.0 untuk Windows. Berikut merupakan ringkasan hasil output SPSS analisis regresi linier berganda pada Tabel 1.

Tabel 1 Ringkasan Hasil Output SPSS Analisis Regresi Linier Berganda

\begin{tabular}{ccccc}
\hline Parameter & Nilai & $P$-value & Alpha & Keputusan \\
\hline $\mathrm{Ryx}_{1}, \mathrm{X}_{2}$ & 0,853 & 0,000 & 0,05 & Menolak Ho \\
$\mathrm{R}^{2} \mathrm{yx}_{1}, \mathrm{X}_{2}$ & 0,727 & - & - & - \\
$\mathrm{Pyx}_{1}$ & 0,290 & 0,000 & 0,05 & Menolak Ho \\
$\mathrm{P}^{2} \mathrm{yx}_{1}$ & 0,084 & - & - & - \\
$\mathrm{Pyx}_{2}$ & 0,523 & 0,001 & 0,05 & Menolak Ho \\
$\mathrm{P}^{2} \mathrm{yx}_{2}$ & 0,273 & - & - & - \\
$\varepsilon$ & 0,273 & - & - & - \\
\hline
\end{tabular}

Berikut adalah kompendium output hasil SPSS analisis regresi linier berganda dalam Tabel 1. Tabel 1 Ringkasan Hasil Output SPSS Analisis Regresi Linier Berganda Berdasarkan Tabel 1 pada atas, maka bisa diketahui output regresi linier berganda menjadi berikut: (1) Ryx1,x2 yang menyatakan interaksi antara variabel kualitas produk dan variabel kualitas pelayanan menggunakan variabel kepuasan pelanggan yaitu sebanyak 0,853. (dua) R2yx1,x2 yang menyatakan akbar sumbangan imbas simultan antara variabel kualitas produk dan variabel kualitas pelayanan terhadap variabel kepuasan pelanggan yaitu sebanyak 0,727 (72,7\%). (tiga) Pyx1 yang menyatakan bahwa interaksi variabel kualitas produk menggunakan variabel kepuasan pelanggan yaitu sebanyak 0,290. (4) P2yx1 yang menyatakan bahwa akbar sumbangan imbas variabel kualitas produk terhadap variabel kepuasan pelanggan yaitu sebanyak 0,084 (8,4\%). (5) Pyx2 yang menyatakan bahwa interaksi variabel kualitas pelayanan menggunakan variabel kepuasan pelanggan yaitu sebanyak 0,523. (6) P2yx2 yang menyatakan bahwa akbar sumbangan imbas variabel kualitas pelayanan terhadap variabel kepuasan pelanggan yaitu sebanyak 0,273 (27,tiga\%). (7) $\varepsilon$ yang menyatakan bahwa akbar interaksi variabel lain sebanyak 0,273 (27,tiga\%). 
Tabel 2 Tabel Hasil t test Dan F Test

\begin{tabular}{ccccccc}
\hline Parameter & $\mathrm{B}$ & $\mathrm{t}_{\text {hitung }}$ & $\mathrm{t}_{\text {tabel }}$ & $\mathrm{f}_{\text {hitung }}$ & $\mathrm{f}_{\text {tabel }}$ & Keputusan \\
\hline Constant & 0,395 & - & - & - & - & - \\
Ryx $_{1}, \mathrm{x}_{2}$ & - & - & - & 129,141 & 3,09 & Menolak Ho \\
Pyx $_{1}$ & 0,157 & 2,982 & 1,984 & - & - & Menolak Ho \\
Pyx $_{2}$ & 0,377 & 6,037 & 1,984 & - & - & Menolak Ho \\
$\varepsilon$ & 0,273 & - & - & - & - & - \\
\hline
\end{tabular}

Dari Tabel 2 dapat dilihat hasil uji regresi berganda memperoleh nilai konstanta $(a)$ sebesar 0,395 nilai koefisien regresi kualitas produk $\left(\beta_{1}\right)$ sebesar 0,157 sedangkan nilai koefisien regresi kualitas pelayanan $\left(\beta_{2}\right)$ sebesar 0,377 dan error sebesar 0,273 . Sehingga persamaan regresi linier berganda sebagai berikut:

$$
\mathrm{Y}=0,395+0,157 X_{1}+0,377 X_{2}+0,273
$$

Berikut ini merupakan penerangan output analisis regresi linier berganda, yaitu: (1) Konstanta yaitu sebanyak 0,395 berarti bahwa bila variabel kualitas produk, variabel kualitas pelayanan dan variabel lain yang memengaruhi nilainya sama menggunakan nol, maka kepuasan pelanggan Toyota Avanza sebanyak 0,395. (dua) Koefisien kualitas produk yaitu sebanyak 0,157 berarti bila variabel kualitas produk semakin tinggi sebanyak satu satuan, maka kepuasan pelanggan akan mengalami kenaikan sebanyak 0,157 sebagai akibatnya sebagai 0,552 menggunakan perkiraan bahwa variabel lainya merupakan permanen. (tiga) Koefisien kualitas pelayanan yaitu sebanyak 0,377 berarti bila variabel kualitas pelayanan semakin tinggi sebanyak satu satuan, maka kepuasan pelanggan akan mengalami kenaikan sebanyak 0,377 sebagai akibatnya sebagai 0,772 menggunakan perkiraan bahwa variabel lainya merupakan permanen.

Hipotesis pertama yaitu "terdapat imbas kualitas produk terhadap kepuasan pelanggan Toyota Avanza". Dari rangkuman analisis, bisa disimpulkan bahwa Ho ditolak, menggunakan output ini adalah terdapat imbas siginifikan menurut kualitas produk terhadap kepuasan pelanggan. Hasil tadi bedasarkan nilai thitung lebih besar menurut ttabel (dua,982 > 1,984) menggunakan $\mathrm{p}$-value lebih mini menurut alpha $(0.004<0,05)$ dengan output ini bisa dipastikan bahwa $\mathrm{HO}$ ditolak. Besaran interaksi imbas kualitas produk terhadap kepuasan pelanggan yaitu sebanyak 0,290 dan sumbangan imbas sebanyak $0,084 \quad(8,4 \%)$, menggunakan output-output tadi maka bisa disimpulkan bahwa kualitas produk berpengaruh positif dan signifikan pada menaikkan kepuasan pelanggan Toyota Avanza.

Hipotesis selanjutnya yaitu "terdapat imbas kualitas pelayanan terhadap kepuasan pelanggan Toyota Avanza". Melihat rangkuman, bisa katakan bahwa Ho ditolak, menggunakan output ini adalah terdapat imbas siginifikan menurut kualitas pelayanan terhadap kepuasan pelanggan. Hasil tadi bedasarkan nilai thitung lebih besar menurut ttabel $(6,037>1,984)$ menggunakan $p$-value lebih mini menurut alpha $(0.000<0,05)$ dengan output ini bisa dipastikan bahwa $\mathrm{HO}$ ditolak. Besaran interaksi imbas kualitas pelayanan terhadap kepuasan pelanggan yaitu sebanyak 0,523 dan sumbangan imbas sebanyak 0,273 (27,tiga\%), menggunakan output-output tadi maka bisa disimpulkan bahwa kualitas produk berpengaruh positif dan signifikan pada menaikkan kepuasan pelanggan Toyota Avanza.

Hipotesis penelitian yang terakhir merupakan "terdapat imbas kualitas produk dan kualitas pelayanan terhadap kepuasan pelanggan Toyota Avanza”. Berdasarkan output uji analisis linier berganda menggunakan pelaksanaan SPSS 23.0 for windows, menerima output bahwa Ho ditolak yang berarti terdapat imbas kualitas produk dan kualitas pelayanan terhadap kepuasan pelanggan. Bedasarkan uji regresi liner berganda yang sudah dilakukan, diperoleh 
output dimana fhitung lebih besar menurut ftabel I $(129,141$ > tiga,09) menggunakan $p$-value lebih mini menurut alpha $(0.000<0,05)$ yang mempertegas bahwa $\mathrm{HO}$ ditolak. Besar interaksi imbas kualitas produk dan kualitas pelayanan terhadap kepuasan pelanggan yaitu sebanyak 0,853 dan sumbangan pengaruhnya sebanyak $0,727(72,7 \%)$ sedangkan sisanya yaitu sebanyak 0,273 atau 27 ,tiga\% ditentukan sang variabel lain menurut luar contoh penelitian.

Hal ini mengidentifikasikan bahwa variabel kualitas produk dan kualitas pelayanan secara bersama-sama berperan pada menaikkan dan menciptakan kepuasan pelanggan Toyota Avanza. Hasil analisis menerangkan nilai $R$ Squere (R2) yaitu sebanyak 0,727 nilai tadi relatif 1 (satu) yang berarti variabel kualitas produk dan kualitas pelayanan menaruh lebih menurut sebagian warta yang diharapkan buat memprediksi variabel kepuasan pelanggan atau bisa diartikan bahwa kualitas produk dan kualitas pelayanan menaruh imbas sebanyak $72,7 \%$ terhadap kepuasan pelanggan Toyota Avanza, ad interim sisanya 27,tiga\% ditentukan sang variabel lain pada luar contoh. Hasil uji analisis linier berganda menerima output bahwa terdapat imbas positif dan signifikan variabel kualitas produk terhadap kepuasan pelanggan Toyota Avanza pada Singaraja.

Dengan mengetahui output penelitian tadi maka bisa disimpulkan bahwa semakin berkualitas produk Toyota Avanza maka kepuasan pelanggan terhadap produk Toyata Avanza semakin besar, sedangkan apajika produk Toyota Avanza mempunyai kualitas yang kurang rupawan maka kepuasan pelanggan Toyota Avanza juga ikut berkurang. Dengan output ini berarti sejalan menggunakan Tjiptono (2006:258) dan penelitian yang dilakukan sang Yuninda (2019). Melihat output tadi maka Toyota Avanza harus menaikan baku kualitas yang mereka terapkan ketika ini. Mengingat bahwa perkara yang mereka hadapi merupakan kepuasan pelanggan yang kurang baik tentu sinkron menggunakan output penelitian menerangkan bahwa kualitas Toyota Avanza kurang baik. Kualitas menurut segi fitur, desain dan lain sebagaianya. Toyota wajib bisa menaikkan kualitas produk mereka semaksimal mungkin tetapi disisi lain mereka wajib menekan porto produksi seminim mungkin, supaya harga jugal nir naik terlalu signifikan. Tentu poly hal yang perlu juga diperhatikan, tetapi perusahaan wajib sesegera mungkin menaikkan kualitas produk mereka ini.

Dari output uji analisis linier berganda menerima output bahwa terdapat imbas positif dan signifikan variabel kualitas pelayanan terhadap kepuasan pelanggan Toyota Avanza pada Singaraja. Dengan menganalisis output penelitian tadi maka bisa disimpulkan bahwa semakin baik pelayanan yang diberikan sang semua karyawan Toyota maka kepuasan pelanggan akan semakin semakin tinggi, sedangkan apajika karyawan Toyota kurang pada menaruh pelayanan yang baik maka kepuasan para pelanggan juga ikut berkurang. Dengan output ini berarti sejalan menggunakan Lupiyoadi (2001) dan penelitian yang dilakukan sang Haryanto (2013). Jika melihat output penelitian menurut imbas kualitas pelayanan terhadap kepuasan pelanggan maka bisa dikatakan bahwa poly Toyota Avanza yang dibeli lantaran selaras menggunakan keadaan ekonomi juga pekerjaan penggunanya. Artinya pengguna menentukan memakai Toyota Avanza lantaran memang mereka mempunyai kecenderungan pada hal keadaan ekonomi dan pekerjaan mereka ketika ini. Dengan kecenderungan antara kepribadian dan kebutuhan inilah yang mengakibatkan mereka menentukan buat membeli Toyota Avanza.

Bedasarkan output perhitungan yang sudah dilakukan, menerangkan bahwa secara bersama-sama variabel kualitas produk dan kualitas pelayanan berpengaruh signifikan terhadap kepuasan pelanggan Toyota Avanza pada Singaraja, menggunakan sumbangan imbas sebanyak $72,7 \%$ sedangkan sisanya 27, tiga\% ditentukan sang variabel lain pada luar contoh. Dengan output ini berarti sejalan menggunakan teori Irawan (2008:37) dan juga 
sejalan menggunakan Amanah (2010) yang mendaptakan output bahwa terdapat imbas yang signifikan positif secara simultan antara kualitas produk dan kualitas pelayanan terhadap kepuasan pelanggan.

\section{Simpulan Dan Saran}

Kesimpulan yang dapat ditarik berdasarkan pembahasan hasil diatas yaitu: kualitas produk berpengaruh positif dan signifikan terhadap kepuasan pelanggan Toyota Avanza di Singaraja. Dengan memahami hasil penelitian tersebut maka dapat disimpulkan bahwa semakin berkualitas produk Toyota Avanza maka kepuasan pelanggan terhadap produk tersebut semakin besar, sedangkan bila produk Toyota Avanza memiliki kualitas yang kurang bagus maka kepuasan pelanggan Toyota Avanza juga ikut berkurang.Kualitas pelayanan berpengaruh positif dan signifikan terhadap kepuasan pelanggan Toyota Avanza di Singaraja. Artinya semakin baik pelayanan yang diberikan oleh seluruh karyawan Toyota maka kepuasan pelanggan akan semakin meningkat, sedangkan bila karyawan Toyota kurang dalam memberikan pelayanan yang baik maka kepuasan para pelanggan juga ikut berkurang. Selain itu, secara bersama-sama kualitas produk dan kualitas pelayanan berpengaruh signifikan terhadap kepuasan pelanggan Toyota Avanza di Singaraja. Artinya bila perusahaan meningkatkan kedua variabel tersebut maka secara efektif akan menignkatkan kepuasan pelanggan pelanggan Toyota Avanza di Singaraja.

Adapun saran yang dapat diberikan kepada manajemen Toyota khususnya Divisi Toyota Avanza di Singaraja perlu lebih memperhatikan dua variabel yang memengaruhi kepuasan pelanggan Toyota Avanza, terlepas dari variabel-variabel lain yang ada di luar fokus penelitian ini. Kualitas produk dan kualitas pelayanan adalah dua variabel yang memengaruhi kepuasan pelanggan Toyota Avanza, dengan demikian manajemen harus meningkatkan kedua variabel tersebut demi meningkatkan kepuasan pelanggan. Program-program terkait upaya peningkatan kualitas produk dan layanan perlu dirancang dan dijalankan secara periodik. Saran lebih rinci terdapat pada bagian implikasi, semoga dapat dijadikan referensi untuk mengambil keputusan selanjutnya. Untuk manjemen utama Toyota divisi Toyota Avanza khususnya yang memegang market Indonesia, diharapkan untuk memberikan ruang bagi manjemen setiap daerah untuk perpendapat, nantinya pendapat-pendapat tersebut di elaborasikan sehingga dapat meminimalisir permasalahan yang terjadi.

Peneliti selanjutnya dapat mengembangkan penelitian ini lebih jauh lagi, misalnya dengan menambahkan variabel independen lain seperti harga dan emosional. Selain itu peneliti dapat juga menguji lebih lanjut kepuasan pelanggan terhadap variabel lain seperti loyalitas pelanggan.

\section{Daftar Pustaka}

Amanah, Dita. 2010. "Pengaruh Harga, dan Kualitas Produk terhadap Kepuasan Konsumen pada Majestyk Backry \& Cake Shop Cabang H.M Yamin Medan". Jurnal Pendidikan Ekonomi. Vol 2, No 1, Tahun 2010: Universitas Negeri Medan.

Ferdinand, Augusty. 2006. Metode Penelitian Manajemen: Pedoman Penelitian untuk skripsi, Tesis dan Disertai IImu Manajemen. Semarang: Universitas Diponegoro

Haryanto, Resty Avita. 2013. "Strategi Promosi, Kualitas Produk, Kualitas Layanan Terhadap Kepuasan Pelanggan Pada Restoran Mcdonald's Manado”. Jurnal EMBA 1465 Vol. 1 No. 4 Desember 2013.

Irawan, Handi, 2008. Membedah strategi Kepuasan pelanggan. Cetakan pertama: PT. Gramedia: Jakarta.

Kotler, Philip. 2002. Manajemen Pemasaran, Edisi Millenium, Jilid 2. Jakarta: PT Prenhallindo. 
Kotler, Philip. 2005. Manajamen Pemasaran, Jilid 1 dan 2. Jakarta: PT. Indeks Kelompok Gramedia.

Kotler, Philip. 2007. Manajamen Pemasaran. Jakarta: PT. Indeks.

Lupiyoadi, Rambat. 2001. Manejemen Pemasaran Jasa. Edisi Kesebelas. Jakarta: Salemba Empat.

Nasution, Nur. 2004. Manajemen Terpadu (Total Service Management). Bogor: Ghalia Indonesia.

Saidani, Basrah dan Samsul Arifin. 2012. "Pengaruh Kualitas Produk Dan Kualitas Layanan Terhadap Kepuasan Konsumen Dan Minat Beli Pada Ranch Market". Jurnal Riset Manajemen Sains Indonesia (JRMSI) |Vol. 3, No. 1, 2012

Sugiyono 2014. Metode Penelitian Pendidikan Pendekatan Kuantitatif, Kualitatif, dan R\&D. Bandung: Alfabeta.

Tjiptono, Fandy. 2006. Strategi Pemasaran. Edisi Kedua. Yogyakarta: Andi.

Tjiptono, Fandy. 2007. Strategi Pemasaran. Edisi Kedua. Yogyakarta: Andi.

Tjiptono, Fandy. 2009. Strategi Pemasaran. Yogyakarta: Penerbit Andi

Yuninda, Firdha. 2019. “Analisis Pengaruh Persepsi Harga Produk, Kualitas Produk, Kualitas Pelayanan Terhadap Kepuasan Pelanggan Implikasi Terhadap Loyalitas Pelanggan (Studi Empiris Pada Perusahaan Kuliner Mantap Boss Jakarta)". 